\title{
AN EVALUATION OF THE USEFULNESS OF CASH FLOW RATIOS TO PREDICT FINANCIAL DISTRESS
}

\author{
L. Jooste, Nelson Mandela Metropolitan University, Port Elizabeth, South Africa.
}

\begin{abstract}
Purpose: With the introduction of the cash flow statement it became an integral part of financial reporting. A need arose to develop ratios for the effective evaluation of cash flow information. This article investigates cash flow ratios suggested by various researchers and suggests a list of ratios with the potential to predict financial failure.

Design: The cash flow ratios suggested by researchers, from as early as 1966, are investigated and eight cash flow ratios selected for inclusion in an analysis to predict financial failure. Ten failed entities are selected for a cash flow evaluation by means of the selected ratios for five years prior to failure. For a comparison, non-failed entities in similar sectors are selected and also evaluated by means of the cash flow ratios. The mean values of each ratio, for each year prior to failure, were then calculated and the means of the failed entities were compared to the non-failed entities.

Findings: The comparison revealed that cash flow ratios have predictive value with the cash flow to total debt identified as the best indicator of failure. It was also determined that, although failed entities have lower cash flows than non-failed entities, they also had smaller reserves of liquid assets. Furthermore, they have less capacity to meet debt obligations and they tend to incur more debt. The ratios of the failed entities were unstable and fluctuated from one year to the next. Finally, bankruptcy could be predicted three years prior to financial failure.

Implications: Income statement and balance sheet ratios are not enough to measure liquidity. An entity can have positive liquidity ratios and increasing profits, yet have serious cash flow problems. Ratios developed from the cash flow statement should supplement traditional accrual-based ratios to provide additional information on the financial strengths and weaknesses of an entity.
\end{abstract}

Key words and phrases: Cash flow statement, ratios, liquidity, financial failure.

\section{INTRODUCTION}

With the introduction of SFAS 95 in the USA and AC 118 in South Africa, the cash flow statement became a mandatory financial statement. This inclusion created a need for cash flow ratios to be included, with traditional balance sheet and income statement ratios, in a financial analysis.

Balance sheet data is static for it measures a single point in time, namely the balance sheet date. The income statement, on the other hand, contains many non-cash transactions, whereas the cash flow statement is dynamic. It records the changes in the other statements over a period and focuses on cash available for operations and investments (Mills \& Yamamura, 1998:53).

The value of cash flow information is that it can be used to assess the quality of earnings, financial flexibility and assists in forecasting cash flows. Cash flow information should also give a better indication of the liquidity of an entity, because nothing is more liquid than cash. If cash flow ratios can be used as a liquidity measure, they can predict financial failure and, ultimately, bankruptcy. Therefore, an early warning of possible financial distress can ultimately help to prevent subsequent financial failure.

Cash flow information can also be useful by complementing the information already provided by accrual accounting. A set of cash flow ratios, if used in conjunction with traditional balance sheet and income statement ratios, can be valuable in determining the financial strengths and weaknesses of an entity (Carslaw \& Mills, 1991:63).

The aim of this article is to select a list of cash flow ratios with the potential to predict financial failure and to investigate the cash flow ratios suggested by researchers from as early as 1966 . Failed and non-failed entities are evaluated by means of selected cash flow ratios. The mean values of each ratio are calculated and those of the failed entities compared to non-failed entities. The results of the ratios are analysed to determine if financial failure can be predicted as well as the time span prior to failure. 
The cash flow ratios are also analysed to determine if one or more cash flow ratios are a better predictor of failure than others.

\section{SELECTING CASH FLOW RATIOS}

An investigation of cash flow ratios revealed that Beaver (1966:71-111) was the first to recognise the importance of operating cash flow as a predictor of financial distress. Four cash flow ratios were included in a financial analysis that concluded that the ability to predict failure was the strongest in the cash flow model. After the pioneering work of Beaver, studies by Giacomino and Mielke (1988:54-57; 1993:55-58), Zeller and Figlewicz (1990:49-59), Carslaw and Mills (1991:63-70; 1993:14-16;), Figlewicz and Zeller (1991:64-81), Stanko and Zeller (1993:83-103), Zeller and Stanko (1994:51-59), Rujoub, Cook and Hay (1995:75-91) and Mills and Yamamura (1998:53-60), were of the first to develop cash flow ratios for inclusion in a financial analysis since the proposal and implementation of SFAC 95 in the USA.

Many of the ratios introduced by earlier authors were duplicated or transformed by other authors (Kuffler \& Leung, 1998:59-60; Ciesielski, 1999:1-13; Gallinger, 1999:40-43; Stickney \& Brown, 1999:154; Palepu, Healy \& Bernard, 2000: 9.15-9.18; Brigham \& Ehrhardt, 2002:46; Brigham \& Davies, 2002:187-188 and Lovemore \& Brummer, 2003). All the later studies, however, stress the importance of cash flows from operations, as opposed to investing and financing activities for reinvestment in assets and payments of obligations. As cash flow from operations is the primary cash generating activity of an entity, an entity will fail if it is unable to produce internally generated cash to finance obligations and if it is unsuccessful in obtaining additional financing. If additional financing is obtained, it should be used for the enhancement of operating activities or productive assets and not to finance debt.

Table 1 lists eight selected cash flow ratios to evaluate failed and non-failed entities.

Table 1: Cash flow ratios selected for financial analysis

\begin{tabular}{|l|l|l|}
\hline \multicolumn{3}{|l|}{ CASH FLOW RATIOS SELECTED FOR FINANCIAL ANALYSIS } \\
\hline NO & CASH FLOW RATIOS & COMPONENTS \\
\hline 1. & Cash flow to sales & $\frac{\text { CFFO* }}{\text { Sales }}$ \\
\hline 2. & Cash flow to assets & $\frac{\text { CFFO }}{\text { Total assets }}$ \\
\hline 3. & Reinvestment & $\frac{\text { CFFO* (after dividends and current debt) }}{\text { Capital expenditure }}$ \\
\hline 4. & Cash flow to total debt & $\frac{\text { CFFO* (after interest) }}{\text { Total debt }}$ \\
\hline 5. & Critical needs coverage & $\frac{\text { CFFO* }}{\text { Interest, current debt and dividends }}$ \\
\hline 6. & Cash interest coverage & $\begin{array}{l}\text { CFFO* (after current debt) } \\
\text { Interest paid }\end{array}$ \\
\hline 7. & Dividend coverage & $\frac{\text { CFFO*(after interest and preference dividends) }}{\text { Ordinary dividends }}$ \\
\hline 8. & Cash flow to income & $\frac{\text { CFFO*(after interest and taxation) }}{\text { Operating Income (after interest and taxation) }}$ \\
\hline
\end{tabular}

${ }^{*}$ Cash flow from operations

The cash flow ratios in Table 1 are selected owing to their popularity and because cash flow from operations is a component of each ratio.

Financial failure in this study means the inability to cover obligations as they become due. According to Mossman, Bell and Swartz (1998), bankruptcy will result if an entity has insufficient cash available to service debt outflows as they become due, and the value of the entity is insufficient to obtain additional financing. Altman and Spivack (1983) agree that the inability of an entity to generate enough cash from its operations may force the entity to borrow more money or to dispose of its productive assets or investments to meet obligations. If this situation persists over an extended period 
of time, it may lead to financial failure. In this regard, Altman and Spivack (1983) and Mossman et al. (1998) find that the inability to finance obligations out of internally generated funds is empirically testable. This has been used to investigate the usefulness of accounting information in other studies successfully.

\section{SELECTING FAILED AND NON-FAILED ENTITIES}

This study, as with earlier studies on bankruptcy prediction (Beaver, 1966; Aziz, Emanuel \& Lawson, 1988 and Laininen, 1994), uses financial statements of failed entities five years prior to failure for analysis. Entities in the public utilities, transportation, investment, insurance and financial institutions are excluded from the evaluation. Their ratios and cash flows are always substantially different from those of other types of entities, even when they are in no danger of failure (Beaver, 1966; Ohlson, 1980; Gilbert, Menon \& Schwartz, 1990 and Mossman et al., 1998).

A list of delisted or suspended entities during 2000 and 2004 was obtained from the JSE. The aim is to select failed entities with financial statements for five years prior to 1996, the year AC 118 (revised) became compulsory in South Africa. Ten failed entities are selected for evaluation and a non-failed entity is selected for a comparison if it suits the following criteria:

- must be in the same sector as the failed entity;

- must have five corresponding financial statements similar to failed entities; and

- must not fall in the list of excluded entities.

Twenty non-failed entities are selected for comparison to the failed entities. The twenty non-failed entities are first evaluated using the K-score (De la Rey, 1981) to determine if they are experiencing financial difficulties. Six non-failed entities are identified not to be financially sound and eliminated from further evaluations.

Table 2 lists the failed and non-failed entities selected for evaluation. The non-failed entities are randomly selected. If one entity does not fit the criteria, the next entity is selected. If no other entity is available, an entity with four corresponding financial statements is selected.

\section{Table 2: List of entities included in analysis}

\begin{tabular}{|l|l|}
\hline \multicolumn{2}{|l|}{ LIST OF ENTITIES INCLUDED IN ANALYSIS } \\
\hline FAILED AND NON-FAILED ENTITIES & INDUSTRY AND INFORMATION \\
\hline DNA Supply Chain Investments Ltd (DNASUP) & Support services business support \\
(failed in 2002) & \\
Bowler Medcalfe Ltd (BOWCAFL) & \\
Nampak Ltd (NAMPAK) & \\
Transpaco Ltd (TRNPACO) & Development capital \\
\hline Dynamic Cables RSA Ltd (DYNAMIC) & Financial statements for four years \\
(failed in 2002) & Excluded, not financially sound \\
Infowave Holdings Ltd (INFOWAVE) & Excluded, not financially sound \\
Integrear Ltd (INTEGREAR) & Retailers soft goods, clothing \\
Stella Vista Technologies Ltd (STELLA) & \\
\hline Fashion Africa Ltd (FASHAF) & \\
(failed in 2002) & \\
Retail Apparel Group Ltd (RAG) & \\
(failed in 2001) & \\
African \& Overseas Enterprises Ltd (AF-\&OVER) & \\
Foschini Ltd (FOSCHINI) & \\
Mr Price Group Ltd (MR PRICE) & Textile household appliances \\
\hline Masterfridge Ltd (FRIDGEM) & \\
(failed in 2000) & \\
Nu-World Holdings Ltd (NUWORLD) \\
Richemont Securities Ag (RICHMONT)
\end{tabular}




\begin{tabular}{|l|l|}
\hline $\begin{array}{l}\text { Rare Earth Co Ltd (RARECO) } \\
\text { (failed 2002) } \\
\text { Lonrho Africa Plc (LONAFRIC) }\end{array}$ & Venture capital (mining \& extraction) \\
\hline $\begin{array}{l}\text { Northern Engineering Industries (Africa) Ltd (NEI- } \\
\text { AFR) } \\
\text { (failed in 2000) } \\
\text { Kairos Industrial Holdings Ltd (KAIROS) }\end{array}$ & Excluded, not financially sound \\
\hline $\begin{array}{l}\text { Siltec Ltd (SILTEC) } \\
\text { (failed in 2000) } \\
\text { Mustec Ltd (MUSTEC) }\end{array}$ & Excluded, not financially sound \\
\hline $\begin{array}{l}\text { Terexko Ltd (TEREXKO) } \\
\text { (failed in 2002) }\end{array}$ & IT hardware computer hardware \\
$\begin{array}{l}\text { Famous Brands Ltd (FAMBRANDS) } \\
\text { Kings Consolidated Holdings Ltd (KINGCO) }\end{array}$ & Financial statements for four years \\
\hline $\begin{array}{l}\text { Universal Growth Holdings Ltd (UNIGRO) } \\
\text { (failed in 2000) } \\
\text { Venter Leisure \& Commercial Trailers Ltd (VENTEL) }\end{array}$ & Leisure and hotel, restaurants, pubs \\
\hline
\end{tabular}

\section{Source: Adapted from list received from the JSE}

Table 2 lists the failed and non-failed entities selected for evaluation. The sector and reasons for exclusions are also listed and two entities are included with four financial statements. The short name of the entity and the year of failure are given in brackets.

The mean values of each ratio for each year prior to failure are calculated for the failed and non-failed entities. The means of the failed entities are then compared to the non-failed entities. The results of the mean values for each ratio are illustrated in Figures 1 to 8 and the analyses of the results are discussed.

The cash flow to sales ratio is calculated in Figure 1. This ratio measures performance and indicates the ability of an entity to generate cash flow, the number of sales that realises in cash. The delivery of goods and services are the primary cash generating activity of an entity. By comparing the return on sales ratio with the cash flow to sales ratio, the analyst can identify the extent to which an entity relies on non-cash items to generate sales, as credit sales, or the shifting of inventory to customers to generate sales. Slow cash collections, for example, will be picked up by the cash flow to sales ratio whereas the return on sales ratio will stay stable (Figlewicz \& Zeller, 1991:69).

\section{Figure 1: Cash flow to sales ratio}

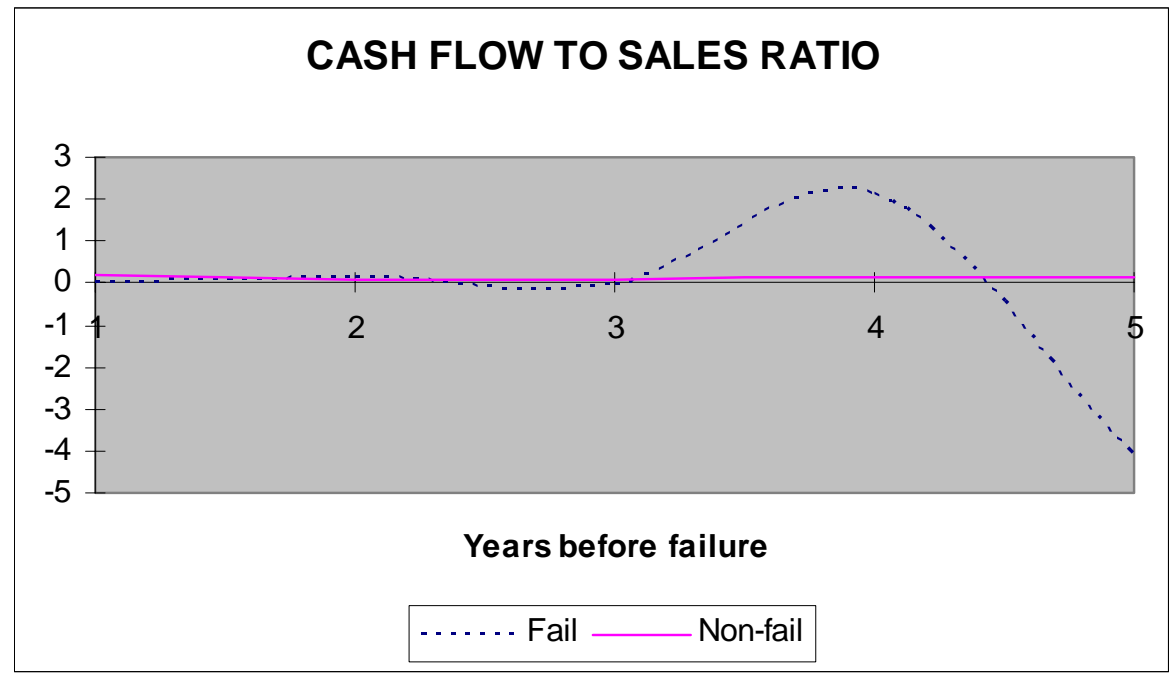


The mean value of the cash flow to sales ratios of the failed entities is weaker than the mean of the non-failed entities in three out of five years. It is not possible to predict failure in the fifth and fourth years prior to failure. The ratios of the failed entities are negative in the fifth year and the increase in cash flow in the fourth year can be due to an increase in sales, as the failed entities were selling stock without replacing it. The ratio of the non-failed entities is stronger in the third and final year of failure. This ratio indicates low values for all entities.

The cash flow to asset ratio illustrated in Figure 2, measures performance and the utilisation of an entity's asset base to create cash flows from operating activities. The traditional return on asset and asset turnover ratios are expected to provide information about asset management and potential future returns to investors. However, the asset turnover ratio only provides information about whether the entity is generating appropriate turnover to support the investment in assets and not whether the investment in assets is sufficient to support future cash flow generation (Zeller \& Figlewicz, 1990:52). The cash generating ability of assets is important in the evaluation of investments in assets, as strong cash returns help generate future investments.

\section{Figure 2: Cash flow to assets ratio}

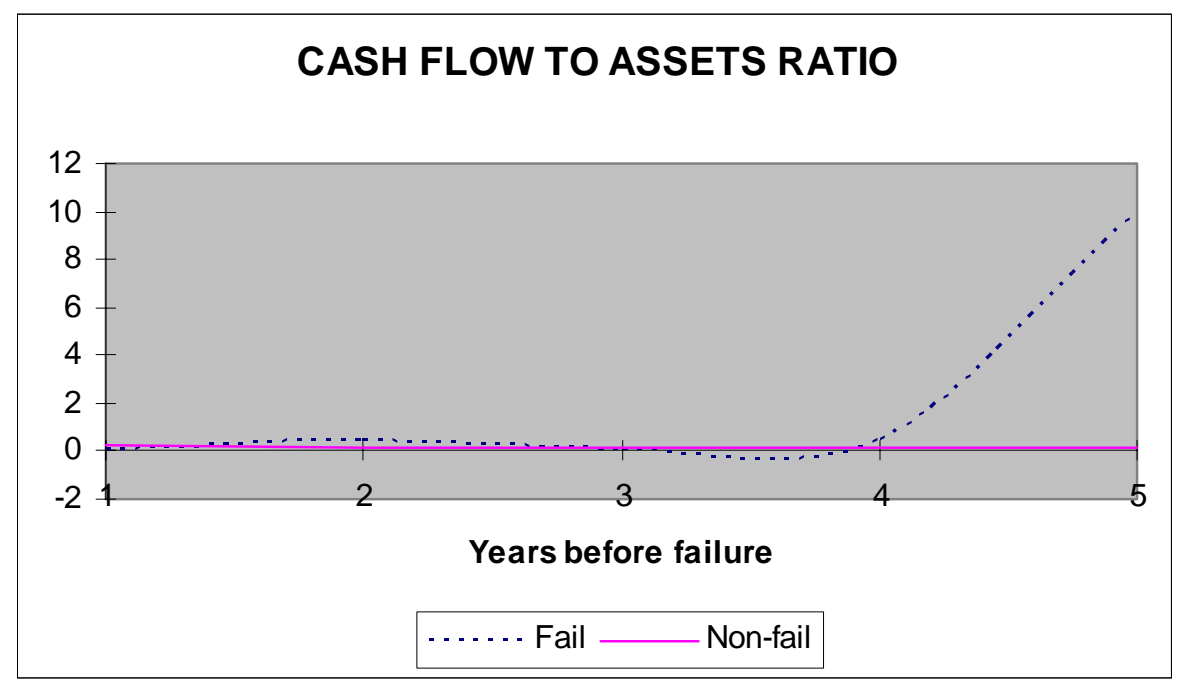

Although the mean value for the failed entities is 790.34 in the fifth year prior to failure, Figure 2 indicates that 10 gives a better indication of differences between small values. The mean value of the failed ratios is weaker than the non-failed ratio in the third and final year of failure only. In normal circumstances, where an entity is financially sound, a low value for this ratio indicates increased investment in assets, as an entity has to maintain an asset base to enhance the ability to generate future cash flows from assets (Carslaw \& Mills, 1991:58 and Rujoub, Cook \& Hay, 1995:80). A decrease in these ratios from the fifth to the fourth year may be due to the lack of reinvestment in assets. An entity should at a minimum reinvest in assets at least at the same rate that it is depreciating assets (Giacomino \& Mielke, 1993:56). The only meaningful conclusion that can be made from this ratio is that the cash generated from assets is low.

In Figure 3, the investment in assets is measured. This ratio is an indication of an entity's ability to finance its capital expenditure from internal sources and whether it is reinvesting in assets faster than writing off depreciation (Giacomino \& Mielke, 1993:56). 
Figure 3: Reinvestment ratio

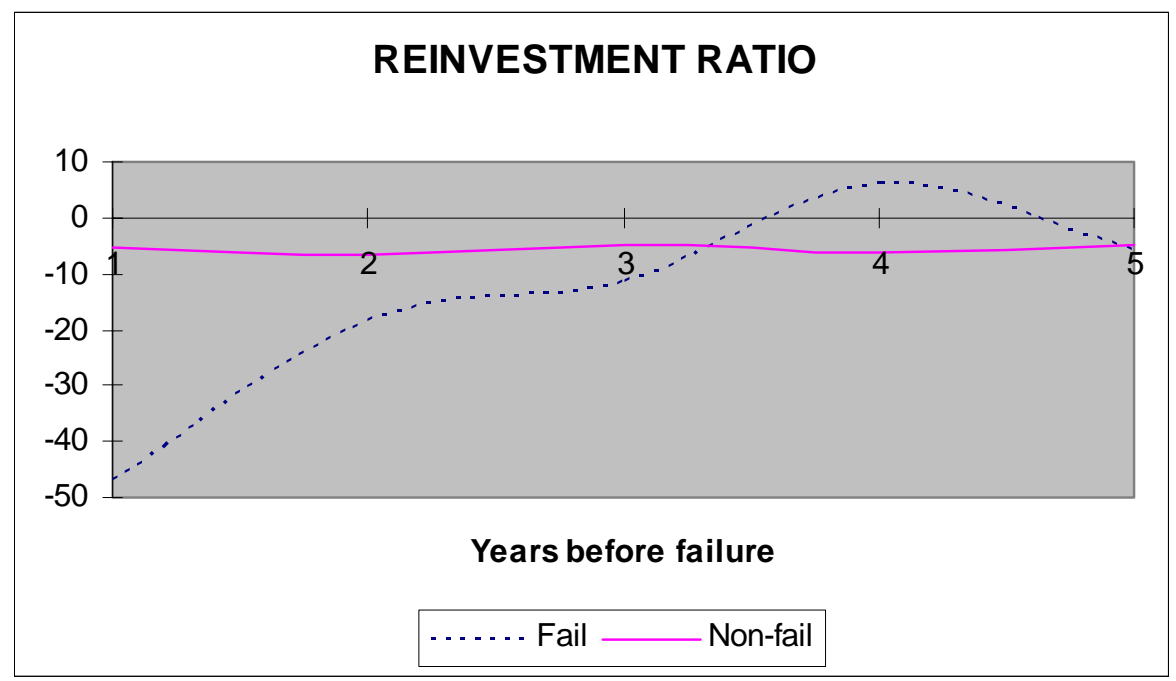

Both the failed and non-failed entities cannot afford capital expenditure and do not have cash flow to reinvest in assets after current debts, interest and dividends are paid. The mean value of the ratio of the failed entities is weaker than the non-failed entities in four out of five years. The reinvestment ratios of the failed and non-failed entities are negative. An entity's competitive advantage depends on its ability to maintain its capital assets. If reinvesting does not occur, the basis for future cash flows could be questioned.

Bankruptcy will result if an entity has insufficient cash available to pay obligations and if the value of the entity is insufficient to obtain additional financing. The cash flow to total debt, as in Figure 4, may be used as a liquidity indicator. It indicates whether an entity can cover obligations as they become due. Beaver (1966) found this ratio to be the most significant in predicting bankruptcy.

\section{Figure 4: Cash flow to total debt ratio}

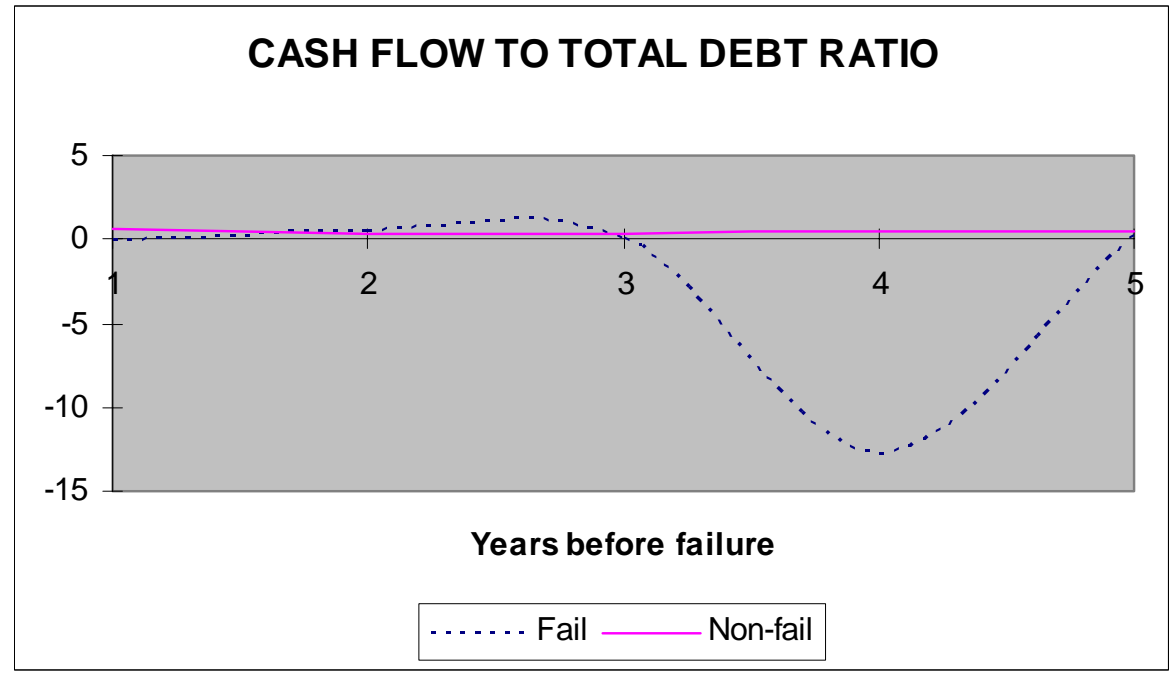

This ratio measures whether debt can be covered by cash flow from operations. The negative ratio of the failed entities indicates that additional measures are needed to cover debt, for example, reliance on outside financing. The cash flow to total debt ratio of the failed entities is weaker than those of the non-failed entities in four out of five years. A decreasing trend may signal a potential problem with 
maintaining operations and debt repayment out of internally generated funds and the need for additional financing to satisfy interest charges, taxes and dividends.

In Figure 5, the critical needs ratio is indicated. Creditors and investors are interested in this ratio as it indicates short-term liquidity. An entity should generate sufficient cash to cover at least its immediate obligations.

\section{Figure 5: Critical needs ratio}

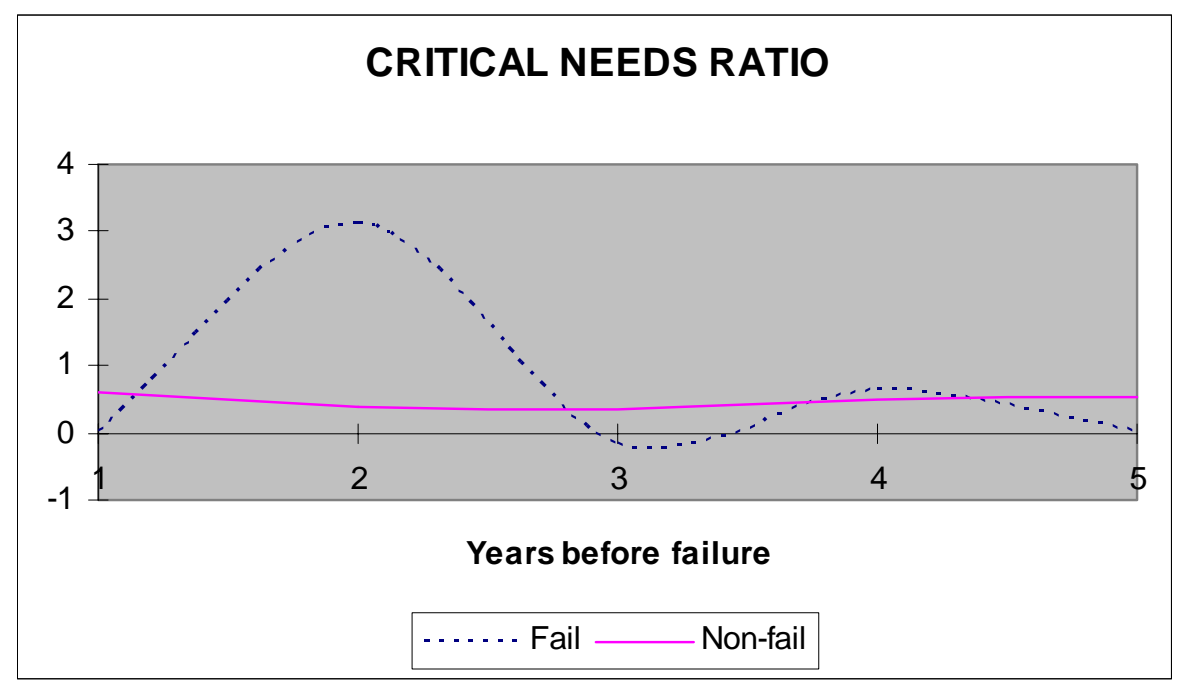

The critical needs ratio is a short-term liquidity measure and indicates coverage of current debt, interest and dividends after normal operating expenses. If an entity is able to cover immediate obligations, it may survive in the long-term. The critical needs ratios of the failed entities improved from the third year prior to failure but insufficient cash was generated to cover total debt.

Traditional activity and coverage ratios fail to capture a specific measure of an entity's liquidity and long-term solvency. Specific cash flow indicators of liquidity and solvency are designed to measure an entity's ability to meet obligations beyond operating needs, such as interest and debt.

The cash to interest coverage ratio, in Figure 6, measures whether cash is available to cover interest payments. During hard times, an entity may rely on outside financing to cover debts. This will increase the interest liability on an entity. If an entity can cover increasing interest payments it may survive, as the debt payments may be taken care of through financing.

This ratio represents net cash flows from operations less current debt available to cover interest. The decreasing trend in the ratios of the failed entities from the fourth year indicates progressive deterioration of future difficulties in meeting interest payments. 
Figure 6: Cash interest coverage ratio

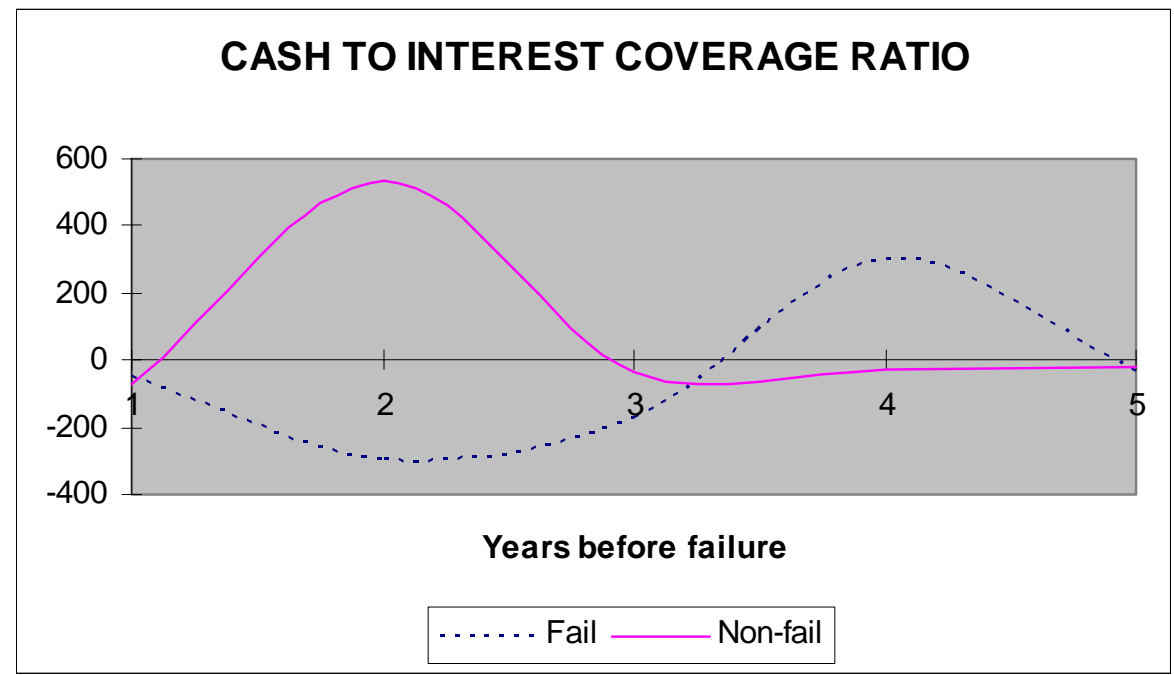

The cash dividend ratio, in Figure 7, measures the cash available for dividends after current debt and interest payments are satisfied. Shareholders want to determine how well their dividends are covered and if the potential exists for increased dividend payments. A decreasing trend in this ratio can indicate potential failure to provide returns to shareholders.

\section{Figure 7: Cash dividend coverage ratio}

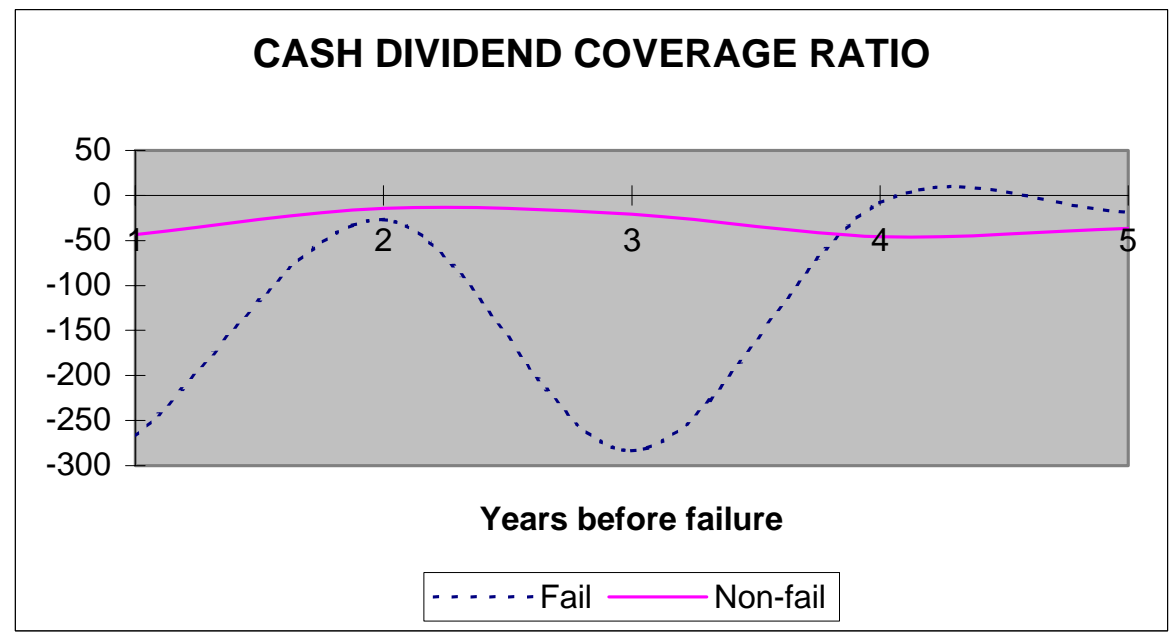

An entity experiencing financial difficulties will tend not to pay dividends. If no dividends are paid for a few years, it could indicate financial difficulties. During such a period, shareholders may be willing to forfeit dividends for survival of the entity. A ratio of less than one indicates that the cash used to pay dividends is not produced solely from operations. Hardly any dividends were paid by the failed entities.

Liquidity is measured by the cash flow to total debt ratio and coverage is measured by the critical needs, interest and dividend coverage ratios. A coverage ratio of less than one indicates that cash used to provide returns to creditors and investors is not provided solely by operations (Figlewicz \& Zeller, 1991:71). 
The cash to income ratio, as measured in Figure 8, measures the quality of income and indicates whether an entity can continue to generate current income levels and invest in assets to improve the quality of future earnings. If this ratio is drawn through to the reinvestment ratio, it will show the ability to generate future earnings from assets. If there is a decline in the cash to income ratio as well as in the reinvestment ratio, it indicates that the entity is not maintaining, or has not generated earnings to maintain its asset base. Therefore, it could not utilise its assets to enhance future earnings and generate cash flows.

Figure 8: Cash to income ratio

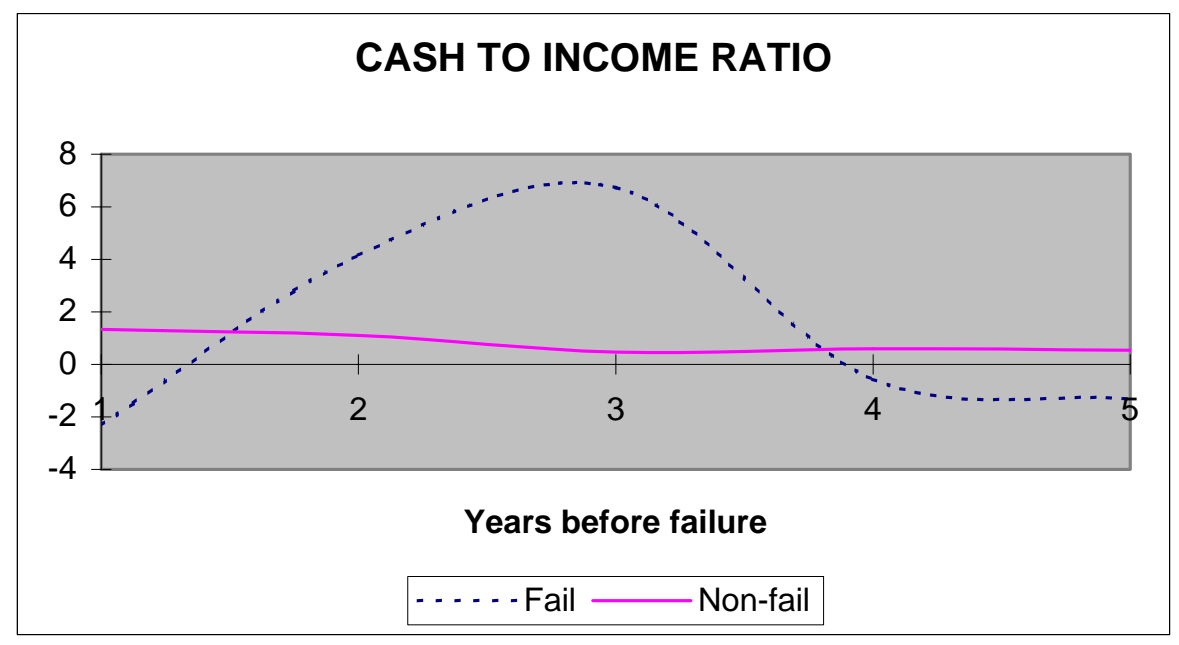

The cash to income ratio also indicates conservatism in calculating income. It measures the stability of income, the relation between income and cash flow and the degree of generating cash flow from operations for asset maintenance and the enhancement of future earnings. This ratio of the failed entities indicates no stability between cash flow and income. The increase in cash flow from the fourth year is due to changes in working capital, expanding receivables or the understatement of payables.

There is always a link between the inflow and outflow of an activity. If any part of the activity fails, it may cause the whole entity to fail.

\section{ANALYSIS OF RESULTS}

An analysis of results found that the failed entities have unusually strong ratios while in financial distress. The individual cash flow statements of the entities were investigated and it was found that the strong ratios are a result of changes in working capital and not a result of increased inflow from turnover or services.

As an example, in the fourth year (1999) prior to failure, Fashion Africa, retailers in the soft goods sector, decreases inventory with close to R126 million. In the year prior to failure, in 2000, Retail Apparel decreases inventory and debtors and increases creditors with nearly R20 million, R15 million and R60 million respectively. In 2001, inventory decreases with close to R48 million and debtors, R12 million.

In the year before failure, Masterfridge decreases inventory with R43 million and increases creditors by R12 million. Dynamic Cables, decreases inventory and debtors with R34 million and R45 million in 2000 , the third year prior to failure. DNA has a change in working capital of R8 million in the fifth year prior to failure. Rare Earth decreases inventory and debtors in the fourth year prior to failure with R4 million. In the final year, in 2002, creditors are increased by R80 million. In the year of failure, 2002, Terexko increases creditors with R6 million, debtors are decreased by R44 million in the fourth year and R15 million in the year prior to failure. 
In the fifth year before failure, six cash flow ratios of the non-failed entities are stronger than the ratios of the failed entities except for the cash flow to assets and dividend coverage ratios of the failed entities. The mean values of the failed entities indicate negative cash flow from sales and income whereas the cash flow to asset ratio indicates that cash can be generated from their asset bases. Entities have to maintain their operating assets to remain competitive. In this analysis, the reinvestment ratio indicates that after providing for current debt, interest and dividends, the failed entities do not have cash flow available to maintain their current asset bases. The cash flow to total debt and coverage ratios indicate that the entities have to rely on other sources to meet their obligations.

In the fourth year, most of the cash flow ratios of the failed entities are stronger than the ratios of the non-failed entities. The cash flow to total debt ratio, however, declines from the fifth to the fourth year. This indicates additional sources of cash to cover debt and interest payments. The cash to income ratio indicates a negative cash flow from operations from the fifth year. A consistent figure that is less than one for the cash to income ratio may indicate that expanding receivables or the understatement of payables are responsible for generating sales (Zeller \& Stanco, 1994:52).

The increase in the cash flow to sales ratio of the failed entities can be a result of decreasing inventory as not enough cash is produced from assets. Funds are available for reinvestment in assets after short-term obligations are met but not available for covering the total debt. In the fourth year, the cash flow to total debt ratio is the weakest and this indicates that the entities are not liquid. Insufficient cash is produced from operations, and the entities have to rely on other sources or outside financing to pay debts. The increase in reinvestment ratio can also be a result of insufficient reinvestment in assets.

The failed entities' cash flow to asset ratio decreases from the fifth to the fourth year. A low return on this ratio, in normal circumstances, can also indicate increases in assets invested (Carslaw \& Mills, 1991:58 and Rujoub, Cook \& Hay, 1995:80). In this case, however, the low value of the ratio is due to insufficient cash realised from assets.

The interest coverage ratio of the failed entities also decreases from the fourth year. A highly leveraged entity will have a low cash interest coverage ratio. A decreasing trend in this ratio indicates progressive deterioration of the entity's future ability to meet interest payments. In the third year, the ratios of the non-failed entities are the strongest, except for the cash to income ratio. Only the cash to total debt ratio, which indicates for the third year insufficient funds to meet obligations, and the cash to income ratio increases. The cash flow to sales ratio decreases, whereas the cash to income ratio increases. This indicates no stability between cash flow and income.

From the third year to the year prior to failure, there is no improvement in the cash flow ratios of the failed entities. The critical needs ratios improve from the third year but insufficient cash is generated to cover total debt. The second year prior to failure is the only year where the cash flow to total debt ratio of the failed entities is stronger than the ratio for the non-failed entities. However, the critical needs ratio only indicates cash flow in the short-term. The individual coverage ratios show insufficient funds for interest and dividends and the failed entities hardly pay any dividends. There are also no internal funds available for reinvestment in assets. The ratios of the non-failed entities are stable except for the improvement in the cash interest coverage ratio.

In the final year, all the ratios of the failed entities are negative and seven of the eight ratios of the failed entities are weaker than the ratios of the non-failed entities. No cash flow is produced from sales and assets. All the ratios decline from the second year, except for the cash flow to interest ratio, which indicates a slight increase.

If all these factors are taken into consideration, it is possible to predict failure in the third year. For the second time in three years, most of the ratios of the failed entities are weaker than the ratios of the non-failed entities. The cash flow to income ratio indicates, in the fourth year, that expanding receivables or the understatement of payables generate sales. The entities cannot generate cash from sales and assets and have to rely on other sources to meet interest payments and pay debts. No cash flow is available to reinvest in an asset base to enhance future production of cash flows. In comparison with the non-failed entities, the mean values of the failed ratios are unstable. 
The cash flow to total debt and reinvestment ratios of the failed entities is weaker than those of the non-failed entities in four out of the five years prior to failure. Therefore, the probability to predict failure must lie with the cash flow to total debt and reinvestment ratios as all ratios do not predict equally well. However, it is more likely that an entity will fail if it does not pay debts than if its reinvestment in assets is insufficient. Furthermore, as financial distress increases, entities will tend to use available funds to pay interest and other debt obligations to survive and they will not use funds to reinvest in an asset base. This is also evident in the cash dividend coverage ratio, as entities with financial difficulties do not pay dividends. Therefore, the best predictor of failure will lie with the cash flow to total debt ratio. The cash flow to total debt ratio is calculated after providing for interest and principal debt. The reinvestment in productive assets will enhance future earnings and will not have an immediate impact on earnings or cash flows. Therefore, a low value for the reinvestment ratio, in normal circumstances, can also indicate substantial investments in assets.

Beaver (1966:80) identified four concepts as important when predicting financial failure. These concepts are:

- Size of the cash reserves;

- Net cash flow from operations;

- Amount of debt held; and

- Operating expenditures.

These concepts can be used to explain the predictive value of the cash flow to debt ratio. The larger the reserves of cash and cash flow from operations, the smaller the probability of failure. Furthermore, the greater the debt and operating expenditure of an entity, the greater is the probability of failure.

This study uses the cash flow from operations after operating expenditure has been paid, adding the changes in working capital that represents the reserve of liquid assets. What remains is available to pay debts. If an entity does not have cash flow to cover its debts over a period of time, it cannot survive.

Any ratio in isolation is not of much use. It has to be incorporated with other ratios or information to have a predictive value. The cash flow to sales ratio is negative in year five and this indicates that not enough cash is generated from operations. This is also evident in the cash to income ratio. As a result, not enough cash is available to pay debts and critical needs, as indicated in the cash flow to total debt and critical needs ratios. This indicates reliance on outside financing or other sources to cover debts. The cash flow from assets ratio indicates that cash is produced from assets but after debts are met, there is no cash flow available for the maintenance of an asset base.

In the fourth and third years, the cash flow to assets ratio declines. A possible reason can be that the asset base was not maintained previously to generate future cash flow from assets. The increase in cash flow to sales ratio indicates that entities tried to generate cash by decreasing inventory and increasing creditors. This was evident in the cash to income ratio. A ratio consistently less than one indicates that sales are generated by means of expanding receivables, decreasing inventory or the understatement of payables. There is no significant increase in the cash flow to assets ratio as there are insufficient funds available for investment in productive assets, interest and dividend payments.

From the third year, the cash to income, reinvestment and cash interest and dividend coverage ratios decline. A comparison between the income and reinvestment ratio indicates that an entity had to maintain an asset base to enhance the ability to generate future income and cash flow from assets. From the third year, all the cash available, whether from operations or changes in working capital, inventory decrease or non-payment of creditors are used to service debts. The cash flow to total debt ratio for the failed entities is stronger than the ratio for the non-failed entities in the year prior to failure.

\section{CONCLUSION}

An analysis of the cash flow ratios revealed that cash flow information has explanatory power. The aim of the analysis is to outline the general relationship between failed and non-failed entities using cash flow information derived from the cash flow statement. The higher the ratio, calculated from the cash flow statement, the lower the likelihood of failure and a positive ratio also indicates positive cash 
flows. Where the mean values are negative, no effective conclusion can be made other than that insufficient cash is available.

Signs of potential financial failure are generally evident in a ratio long before the entity actually fails. In this regard, the failed entities have lower cash flows than non-failed entities and smaller reserves of liquid assets. They also have less capacity to meet obligations and they tend to incur more debt. The changes in working capital also have an effect on the results of ratios. A decrease in inventories means that the entity is selling inventories and not replacing them and, therefore, generating cash. When payables increase, the entity receives additional credit that saves cash. In the fourth year and the year prior to failure, the changes in working capital cause failed entities to have positive cash flows while in other years, they experience negative cash flows.

\section{REFERENCES}

Altman El \& Spivack J. 1983. Predicting bankruptcy: The value line relative financial strength system versus the Zeta bankruptcy classification. Financial Analysts Journal, 39:60-67.

Aziz A, Emanuel DC \& Lawson. 1988. Bankruptcy prediction - an investigation of cash flow based models. Journal of Management Studies, September:419-437.

Beaver WH. 1966. Financial Ratios as predictors of failure. Journal of Accounting Research (Supplement):71-111.

Brigham EF \& Daves PR. 2002. Intermediate Financial Management, $7^{\text {th }}$ ed. South-Western: Thompson Learning.

Brigham EF \& Ehrhardt MC. 2002. Financial Management Theory and Practice. $10^{\text {th }}$ ed. SouthWestern: Thompson Learning.

Ciesielski JT. 1999. 'Cash-flavoured' earnings: bogus performance measure. The Analyst's Accounting Observer, 8(8):1-17.

Carslaw CA \& Mills JR. 1991. Developing ratios for effective cash flow statement analysis. Journal of Accountancy, November:63-70.

Carslaw CA \& Mills JR. 1993. Including the cash flow statement in financial analysis. Executive Accountant, Autumn:14-16.

De La Rey JH. 1981. Finansiële verhoudingsgetalle en die voorspelling van financiële mislukking by nywerheidsondernemings in die Republiek van Suid-Afrika. Pretoria: University of Pretoria. (Unpublished Doctoral Script).

Figlewicz RE \& Zeller TL. 1991. An analysis of performance, liquidity, coverage and capital ratios from the statement of cash flows. ABER, 22(1):64-81.

Gallinger GW. 2000. A framework for financial statement analysis part 1: Return-on-asset performance. Business Credit, 102(2):40-43.

Giacomino DE \& Mielke DE. 1988. Using the statement of Cash flows to analyze corporate performance. Management of Accounting, May:54-57.

Giacomino DE \& Mielke DE. 1993. Cash flows: another approach to ratio analysis. Journal of Accountancy, March:55-58.

Gilbert LR, Menon K \& Schwartz KB. 1990. Predicting bankruptcy for firms in financial distress. Journal of Business Finance \& Accounting, 17(1):161-171.

Kuffler LA \& Leung RM. 1998. Rating criteria for global project and infrastructure developers. Journal of Project Finance, 4(1):55-67. 
Laitinen EK. 1994. Traditional versus operating cash flow in failure prediction. Journal of Business Finance \& Accounting, vol. 21(2):195-217.

Lovemore FCH \& Brummer LM. 2003. The ABC of Financial Management: An Introduction to Financial Management and Analysis. $2^{\text {nd }}$ ed. Pretoria: Van Schaik.

Mills JR \& Yamamura JH. 1998. The power of cash flow ratios. Journal of Accountancy, 186(4):5360.

Mossman CE, Bell GG \& Swartz LM. 1998. An empirical comparison of bankruptcy models. Financial Review, 33(2):35-55.

Ohlson JA. 1980. Financial ratios and the probabilistic prediction of bankruptcy. Journal of Accounting Research, Spring:109-131.

Palepu KG, Healy PM \& Bernard VL. 2000. Business Analysis \& Valuation: Using Financial Statements. $2^{\text {nd }}$ ed. Mason: Thompson Learning.

Rujoub MA, Cook DM \& Hay LE. 1995. Using cash flow ratios to predict business failures. Journal of Managerial Issues, 7(1):75-91.

Stanko BB \& Zeller TL. 1993. Cash flow ratios to measure liquidity and performance for transportation manufacturing firms. Journal of Transportation Management, V(2):83-103.

Stickney CP \& Brown PR. 1999. Financial Reporting and Statement Analysis. Ford Worth: Dreyden Press.

Zeller TL \& Figlewicz RE. 1990. New investing and financing activity ratios from the statement of cash flows enhance traditional ratio analysis in assessing future cash flows. The Mid-Atlantic Journal of Business, 26(2):49-59.

Zeller TL \& Stanko BB. 1994. Operating cash flow ratios measure a retail firm's "ability to pay". Journal of Applied Business Research, 10(4):51-59. 